\title{
Development of Container Rail Transportation with using Intelligent Cognitive Technologies
}

\author{
Denis Lomotko* and Danil Arsenenko \\ Department Transport system and Logistic, Ukrainian State University of Railway Transport, Ukraine
}

Submission: April 06, 2019; Published: June 25, 2019

*Corresponding author: Denis Lomotko, Department Transport system and Logistic, Ukrainian State University of Railway Transport, Kharkiv, Ukraine

\begin{abstract}
Enlargement of the EU and the intensification of the processes of European integration of transport borders requires a new orientation of traffic flows and the development of the national transport network. The transformation of national transport systems into a single trans-European network TEN-T will constitute the basis of the EU's infrastructure policy. The growth of container trades is one of the main trends implied in the development of the international transport system. This makes it necessary to the need to develop container transport infrastructure of civil engineering. However, modern traffic corporatization processes result in the imperative need for the door-to-door coordination process in container terminals. It is proposed to improve the logistics chain with harmonization of rules made by creating regulations to include all modes of transport in such logistic chains according to the directive of the "intelligent" transport systems (Directive 2010/40 / EU of 07.07.2010) was based on the standard ISO 14813-1.
\end{abstract}

Keywords: Logistics technology; Container; Railway transport; Cognitive Technologies; Supply chain management

\section{Introduction}

Enlargement of the European Union and the intensification of the processes of European integration of transport borders requires a new orientation of traffic flows and the development of the national transport network. The framework of the infrastructure of EU policy is the transformation of the national transport systems into a single trans-European transport network (TEN-T). The main trends of development of the international transport system is the expansion of container traffic. This makes it necessary to the need to develop container transport infrastructure of civil engineering. Modern processes of corporatization in transport direct to the need for end-toend coordination of the cargo delivery. So, there is a need in the preparation and effective use of huge amounts of information logistic. This can be done with the use of cognitive technologies in development of transport infrastructure. The global trend is associated with a growth in the volume of container shipments and the formation of large container shipping companies. Those in turn need civil engineering transport facilities [1].

\section{Formulation of the Problem}

In the process of shipping containers, national supply chains are limited to one country, and international ones to several countries. Thus, organizers, suppliers, customers and all participants in the supply chain can be located within one or more countries. Due to the complexity of such transnational systems and its transport infrastructure civil engineering, the processes of managing container flows should be based on the principles of Supply Chain Management (SCM) with the organization of strategic alliances. This can be realized by introducing cognitive technology VMI (Vendor-Managed Inventory), which is the development of vertical cooperation of consumers and suppliers in the field of resource management. Cognitive system (from the Latin Cognito - cognition, learning, familiarization) - a multi-level system that provides all the basic cognitive functions of a living organism. This system ensures that all stages of the process of cognition, and also includes a number of mandatory subsystems - perception, attention, memory, thinking, etc. Cognitive technologies «imitate» a human thinking and frequently core the «Internet of things» (IoT) or the «smart house» ideology, using models with neural networks and fuzzy logic [2].

\section{Ways to Solve the Problem}

The cognitive model of the logistics system determines the structure and functions of the decision support system by the management personnel. The formalization of the cognitive model is carried out in the form of a tuple

$$
\mathrm{CLS}=<\mathrm{G}, \mathrm{X}, \mathrm{U}, \Psi>
$$

where $\mathrm{G}=<\mathrm{V}, \mathrm{E}>$-oriented graph;

$\mathrm{V}=\{\mathrm{vi}\}$-array of vertices of the graph (elements of the studied logistic system), $\mathrm{i}=1,2 \ldots . ., \mathrm{K} ; \mathrm{K}-$ number of vertices of the graph. 


\section{Civil Engineering Research Journal}

$\mathrm{E}=\{$ eij $\}$ - array of arcs (relations of elements of the logistic supply chain) between vertices, $i, j \in[1, \mathrm{~K}]$. There eij reflects the degree of influence (both positive and negative) from vertices $\mathrm{Vi}$ to vertices $\mathrm{Vj}$.

$\mathrm{X}$-array of parameters of vertices on a given time interval $\mathrm{Tn}=\{\mathrm{t} 1, \ldots \ldots, \mathrm{tn}\}, \quad \mathrm{X}: \mathrm{V} \rightarrow \Psi, \quad \mathrm{XVi}=\{\mathrm{g}(\mathrm{xi} \in \Psi)\} ; g \in[0,1]-\quad$ vertex parameter $\mathrm{Vi}$ in the form of a single Heaviside function.

$\Psi$ - space of possible parameters of vertices.

$\mathrm{U}=\mathrm{f}(\mathrm{X}, \mathrm{E})$-complex arc-transformation functional, $\mathrm{U}: \mathrm{E} \times X \times \Psi \rightarrow R$ (R - real numbers array). In fact, dependence $\mathrm{f}(\mathrm{X}, \mathrm{E})$ may be not only functional, but also a stochastic, in the form of regression equations, or as an expression of the fuzzy. Defining the parameters $f(X, E)$ represents the management function in the logistics system, it may include the preferences of the person making management decisions.

Formal rules, standards and technical rules between the elements of the supply chain of container cargo can be drastically different. In the EU, harmonization of rules made by creating regulations to include all modes of transport in such logistic chains according to the directive of the «intelligent» transport systems (Directive 2010/40/EU of 07.07.2010) was based on the standard ISO 14813-1. European legal system treats intellectual transport system as a system, which uses communication, transport infrastructure and information technologies in the field of transport. This system should be able to interact with other modes of transport, including vehicles, infrastructure, civil engineering logistics, other participants in the system using the transport regulation system [3].

Development of transport infrastructure makes it necessary the rational use of corporate logistics market especially the use of behavioral patterns and models for the formation of supply chains. Typically, supply chain are complex array of series of interacting subsystems of the resource providers and consumers. In this case, each element in the process of promoting the logistics container flow becomes supplier for the following items as long as the finished product is not received by the end user. The supply chain of logistics container flows includes the supply company, suppliers, consumers and a various intermediary. These nets become an integral part of international logistics systems and provide reliable and uninterrupted delivery of container goods by various modes of transport. This system is complex, they can consist of several independent supply chains and require special technologies to effectively manage them. A rational method is to manage the container transport system from the perspective of a complex cognitive one with the aim of optimizing it.

The tasks of creating cognitive transport systems - obtaining, processing and intelligent use of logistic data flows, decisionmaking process in difficult technological situations. The main participants and components of cognitive transport systems are:

1) Transport infrastructure

2) Civil engineering transport facilities
3) Remote control systems with transport infrastructure elements and vehicles

4) Intelligent information technologies with the ability to remotely manage objects

5) Analytical centers for the collection, processing and preparation of logistics information

6) Centers for decision making and management of logistical flows

7) These components define the main tasks of container transportation systems

8) Choosing the type of civil engineering container objects (terminals, railway tracks, etc.)

9) Planning the transport process in conjunction with the terminal, warehouse and manufacturing;

10) Coordinated planning of technological processes in different modes of transport

11) Provision of interoperability (technological unity, ISO/IEC 21823-1:2019) of transport, warehouse distribution and manufacturing processes

12) Determination of rational routes for the delivery of containerized cargo.

The growing demand for rail container transportation by sellers and buyers leads to search results ready technical and technological solutions forming logistic chains delivery of containerized cargo. Choosing an effective set of solutions allows us to realize the scheme of delivery of cargoes in the limited time of delivery and reducing transport costs.

However, due to the uneven distribution of container freight traffic on the transport network, a system of delivery of containerized cargo with different efficiency performance of logistics operations is formed. This is due to the different technical characteristic of each mode of transport by region, the differentiation of the level of competitiveness of suppliers and consumers, the level of infrastructure development (especially in EU transport corridors). Transportation in universal and specialized containers lead to the development of appropriate infrastructure in container terminal systems, transport and logistics centers, analytical management centers. Improve the efficiency of the whole supply chain contributes to the efficient management and preparation of logistics information, which may be based on the use of logistics cognitive technologies.

\section{Conclusion}

Due to the formation of new transport links, favorable conditions for increasing the volumes of containerized transit cargo transportation and attracting investments are created. Thus, the container transport system on domestic railways with advanced logistics cognitive technologies will be able to reach a new level of development a civil engineering logistics object. 


\section{Civil Engineering Research Journal}

\section{References}

1. Butko T, Prokhorchenko A, Muzykin M (2016) Improvement of methods for determining the circulation patterns of locomotives taking into account the technological features of traffic flows // East European Journal of Advanced Technologies. Pp. 47-55.

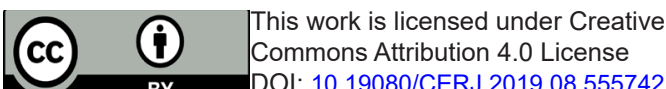

2. organisation internationale de normalization (1947), Europe.

3. Lomotko DV, Kovalev AO, Kovaleva OV (2015) Formation of fuzzy support system for decision-making on merchantability of rolling stock in its allocation //Eastern-European Journal of Enterprise Technologies. Open journal system 6(78): 11-17,

Your next submission with Juniper Publishers will reach you the below assets

- Quality Editorial service

- Swift Peer Review

- Reprints availability

- E-prints Service

- Manuscript Podcast for convenient understanding

- Global attainment for your research

- Manuscript accessibility in different formats ( Pdf, E-pub, Full Text, Audio)

- Unceasing customer service

Track the below URL for one-step submission https://juniperpublishers.com/online-submission.php 